\title{
ENVIRONMENTAL REQUIREMENT INTEGRATION INTO THE LAND LAW OF VIETNAM
}

\author{
MAI THANH DUNG, NGUYEN MINH KHOA* AND PHAN THI THU HUONG \\ Institute of Strategy and Policy on Natural Resources and Environment, 479 Hoang Quoc Viet, Hanoi 100000, Vietnam. \\ *Corresponding author: ngmikh@gmail.com \\ Submitted final draft: 27 September $2020 \quad$ Accepted: 25 December $2020 \quad$ http://doi.org/10.46754/jssm.2021.10.016
}

\begin{abstract}
Integrating environmental protection requirements into land law is a matter that needs serious consideration in Vietnam for two reasons: on one hand, the current regulations of environmental protection in land law are still vague and meagre; on the other hand, unsustainable land management and use are causing serious environmental problems, manifested by contaminated soil and an increase in degraded land and desertification. Environmental protection considerations in land-use planning are also limited, resulting in ineffective environmental protection through land use. Therefore, integrating environmental protection requirements into land law is an idea that is attracting much attention in Vietnam. Given the situation, this paper clarifies the issues of environmental protection in land law and proposes content for the environmental protection requirements that need to be integrated into Vietnam's land law.
\end{abstract}

Keywords: Integrating environmental protection requirements, sectoral legal systems, environmental policy integration, land law, Vietnam.

\section{Introduction}

Land plays a very important role in every country because all socioeconomic development activities are associated with land-use practices. Therefore, environmental protection through land management has great significance for realising sustainable development, ensuring that environmental factors are always fully considered in all processes, from planning to exploitation, and from the use to the promotion of land potential.

The Law on Environmental Protection of 2014 has a section on soil environment protection, including three articles on general provisions for soil environment protection, soil environment management and soil environment pollution control. According to these regulations, all activities using land must consider the soil environment and offer solutions to protect the soil environment. Organisations and individuals assigned land-use rights must be responsible for protecting the soil environment; anyone who causes soil environmental pollution must be responsible for treating, improving and restoring the soil environment. The law requires the government to provide articles with detailed regulations for soil pollution control to ensure that factors that are likely to cause land pollution are identified and controlled. State management agencies in charge of environmental protection are required to organise the control of soil environmental pollution. Production, business and service establishments are responsible for controlling soil pollution at their facilities.

The Law on Land of 2013 put environmental protection requirements into land use and landuse planning principles. However, the Law on Land of 2013 regulations on environmental protection through land management were very vague, stipulating only general principles that lacked specific provisions for land environmental protection, even though land management is the enterprise that exerts the greatest control on the environment. The integration of environmental protection requirements into land law is limited to only these general principles, while there is a lack of specific and feasible regulations on environmental protection in the field of land management, as discussed below. It is necessary to have a more specific and detailed 
integration of specialised environmental protection requirements added to the land legal system to address the current shortcomings and constraints, thereby improving the efficiency of environmental protection in land management.

\section{Materials Studied and Method}

Underdal (1980) first created the concept of policy integration, and discussed the general meaning of policy integration, but not specifically mentioning environmental policy integration (EPI). Underdal's approach to the issues is essential when focusing on the way policymaking processes can be described. Based on the research by Underdal (1980), Collier (1994) and Peters (1998) on policy integration, EPI has been further developed. EPI is driven by the recognition that each industry or sector will not be able to realise its own environmental goals by itself. Each sector must consider environmental policy goals if the overall environmental goals are to be achieved (Lafferty \& Hovden, 2003). Persson (2004) studied an overview of EPI from the formation process and related studies, and specifically investigated the EPI evaluation criteria. Runhaar (2016) summarised the tools for integrating environmental objectives into policy and implementation practices and assessed the effectiveness of these tools.

At the national level, Fidelis (2005) analysed the problem of integrating environmental issues in the Portuguese planning system and identified existing problems and challenges. Bugge (2010) investigated the fragmentation in environmental law and discretionary decision-making through the case of Norway, while Ahmed (2017) investigated Ethiopian sectoral laws with the aim of analysing the nature, scope and extent to which environmental norms and principles are incorporated into these laws.

In Vietnam, research on integrating the environment into the sectoral legal system is still a relatively new matter, as the number of studies related to this topic is still quite meagre (Mai et al., 2019). Insofar as any endeavour relates the integration of environmental protection requirements into the land law of Vietnam, only one project, funded by the Swedish government in 2007, mentioned the integration of the land and environment into land legislation (SEMLA, 2007). This pilot project merely sketched some requirements of environmental integration into the land law before the project was unfortunately discontinued. Thus, it is necessary to have a more specific and detailed integration of specialised environmental protection requirements into the land legal system.

Secondary information and data used in this study include officially published sources of domestic and foreign authors on environmental integration in development policy and sectoral laws, as well as related studies. Primary data were obtained from information collected through interviews and consultation with research organisations and experts.

To assess the potential and effectiveness of integrating environmental protection requirements into a sectoral law, these considerations are proposed:

- The scope and severity of the impacts of such sectoral law on the environment: These are the first considerations that need to be determined because the sectoral law should have a meaningful impact on the environment, and there are major environmental issues involved;

- The degree to which environmental protection requirements are to be integrated into the current sectoral law: Whether environmental protection regulations in the sectoral law, as well as the extent and effectiveness of current integration, need to be determined;

- $\quad$ Requirements to be integrated: The content that needs to be specifically integrated into the sectoral legal system, at the law level or bylaw level, must be discerned; and,

- Feasibility of integration: The feasibility and effectiveness of the integration must be determined to identify its impacts and possible benefits. 
In the next section, we discuss in detail the application of these considerations on Vietnamese land law and highlight the necessity of environmental integration into the land law and components of the law that should incorporate environmental requirements.

\section{Results and Discussion}

\section{Land Management and Environmental Impacts}

Environmental protection in land management has great significance for realising the goal of sustainable development. However, the soil environment is facing many challenges.

First, pollution of the soil environment is due to the excessive use of chemical fertilisers. The National Environmental Report for the period of 2011-2015 (MONRE, 2015) shows that chemical fertilisers are commonly used in agricultural production due to their cost advantages and efficiency for treating crops. As a result, the soil quality is reduced, with an accumulation of nitrate, ammonium and some heavy metals. In some specialised agricultural areas in both the north and south of the country, years of investigation have revealed a soil environment with negative to neutral reactions, with $\mathrm{pH}_{\mathrm{KCI}}$ values ranging from 4.56 to 6.62 (MONRE, 2015). Soil in many agricultural areas has a heavy metal content exceeding the permitted level for agricultural land. In addition to chemical fertilisers, the overuse of plant protection chemicals to control pests and diseases in crops has led to an increase in pesticide residue in some rural areas.

Second, economic development activities increase the source of emissions. The soil environment is affected by pollutants from industrial activities, construction and living activities, and is most evident in areas surrounding large urban centres or in areas where industrial and mining activities are concentrated. The increase in wastewater from industrial zones in the southern provinces in recent years has been enormous. In areas affected by craft village wastewater, especially in villages that have unofficial recycling activities, the quality of soil has been reduced. In addition, Vietnam's soil environment is also affected by residual toxic chemical pollution sites as a result of the Vietnam War. According to the list of residues of plant protection chemicals that cause serious and extremely serious environmental pollution, there are currently 240 pesticide residue sites in 15 provinces/cities nationwide (MONRE, 2015).

Third, groundwater recession and desertification in Vietnam are still serious problems (Table 1). Vietnam has 13,048 $\mathrm{km}^{2}$ of degraded land, totalling $4 \%$ of the total area; $24,043 \mathrm{~km}^{2}$ of the land shows signs of degradation, totalling $7.3 \%$; and $67,005 \mathrm{~km}^{2}$ of land are at risk for degradation, totalling 20.4\% (LDN TSP, 2018). In addition to the desertification of land, many coastal sandy areas of Vietnam are also subject to localised desertification, concentrated from the Quang Binh to the Binh Thuan provinces, with an area of approximately 419,000 hectares and in the Mekong Delta with 43,000 hectares (MONRE, 2015). According to statistics from FAO and UNESCO maps, Vietnam has approximately 462,000 hectares of coastal sand, accounting for approximately $1.4 \%$ of the total natural area of the country, of which 87,800 hectares are sand dunes and large sand dunes (MONRE, 2015). For nearly 40 years, the movement of sand dunes has made the process of desertification even more serious. Each year, sand encroaches on approximately 10-20 hectares of arable land, leading to a sharp decrease in soil fertility. Production planning and land-use planning are based on meeting immediate needs and benefits, which do not take into account the long-term harm to the ecological environment or deforestation and are the main reasons for soil degradation and desertification.

\section{Current Status of Environmental Integration into Land Law}

The integration of environmental protection requirements into land law does not seem to be properly focused on by lawmakers, with 
Table 1: Distribution of the degraded land by region

\begin{tabular}{clcc}
\hline No. & \multicolumn{1}{c}{ Region } & $\begin{array}{c}\text { Acreage } \\
\text { (thousands of ha) }\end{array}$ & $\begin{array}{c}\text { Degraded and Un- } \\
\text { used Land (\%) }\end{array}$ \\
\hline 1 & $\begin{array}{l}\text { Northern midland moun- } \\
\text { tainous region }\end{array}$ & 6705.6 & 70 \\
2 & Northcentral region & 2522.4 & 54 \\
3 & Southcentral region & 2704.2 & 61 \\
4 & Central highlands & 1374.3 & 47 \\
\hline
\end{tabular}

Source: MONRE, 2010.

policy analysis, social needs assessment and survey results reflected in the requirement contents (Nguyễn, 2009). As a result, the land law lacks specific and feasible regulations on environmental protection through land management.

The Law on Land of 2013 regulations related to environmental protection in land management were negligible, providing only a few general principles without specific regulations on environmental protection of the land. Therefore, in terms of land use, environmental issues have not been given appropriate attention, and, in many cases, they are completely overlooked.

One of the basic reasons for the restrictions is that the integration of land issues and environmental protection in drawing up land laws seems to have been inconsistently implemented. There has been no integration of environmental protection issues in land-inspection activities. Environmental protection issues are still very watered down in regulations on the use and management of urban land. Regarding land management in industrial parks and economic zones, there is a lack of specific regulations on land-use planning for the construction of waste treatment facilities and the planning of waste dump sites in industrial parks and production facilities (Nguyễn, 2009). The desertification problem is quite serious as discussed above. But currently, there are no specific provisions in the legal system to prevent or combat this problem. Environmental issues in land-use planning, despite having a great impact, have not yet been given appropriate attention.

Furthermore, investors currently pay little attention to environmental impact assessments (EIA) when implementing real estate investment projects, and very few projects are not approved because of a lack of EIA. Until recently, there has been no specific regulation on environmental protection for a project during all stages of preparation, construction, trial operation, commercial operation and project closure (Pham et al., 2020), while some provisions in the law, such as the Law on Investment, Law on Construction, Law on Mining, Law on Land, and Law on Environmental Protection, lack uniformity regarding investment project approval (MONRE, 2020).

Regarding the conflict of laws, the Law on Promulgation of Legal Documents 2015 (Article 156) applies the principles of Lex posterior derogat legi priori (a later law repeals an earlier law) and Lex specialis derogat legi generali (a special law repeals general laws). However, this is a controversial issue and causes much confusion during implementation, including difficulty in determining which is the general law and the special law in each case, and some concerns that the application of these principles can lead to environmentally negative impacts due to the lack of specific environmental regulations in the special legislation (Thái, 2011; Lê \& Nguyễn, 2020). 


\section{Environmental Requirements Need to be Integrated into Land Law}

Considering the abovementioned constraints, there is a need to supplement and fulfil regulations on environmental protection in the land law in the direction of ensuring consistency with the law on environmental protection, focusing on environmental factors in the process of planning and land allocation, use, land acquisition and protection of the soil environment. The integration should aim to ensure that all land use requirements are met (from decisions related to land use surveys, assessments and planning, to decisions to allocate, lease, use, acquire and handle land violations) and must factor and incorporate environmental protection requirements (related to land) into these decisions appropriately (SEMLA, 2007).

Specific regulations on soil environment protection, prevention of land degradation and desertification must be developed. Currently, there are no specific provisions in the legal system to prevent and combat the desertification problem despite it being quite serious. Therefore, preventing land degradation and desertification is one of the basic focuses in integrating environmental protection into land law.

In addition, the Law on Land should be integrated, emphasising the need to assess the environmental impact of real estate investment projects during the approval process, as well as the project implementation process. Environmental impact is considered an important factor in the approval decision because, in the past, this issue has been neglected or not taken seriously, leading to many environmental problems with real estate projects.

It is also important to underline the need to raise and promote awareness of the environmental compliance of organisations and individuals in the course of land use. In fact, although the current law is quite strict on the use of pesticides and acts leading to land destruction, the people themselves are not equipped with the legal knowledge or scientific awareness of the matter, and most of them still follow habitual practices. In many cases, farmers have been well informed about the legal and technical aspects, but their awareness of environmental protection is not high; they consider only immediate benefits while neglecting long-term benefits. Sanctions against violations of the law in the field of environmental protection during agricultural land use are not strict, and the inspection, examination and handling of violations remain weak (Nguyễn \& Đỗ, 2015). The reduction, recycling, and reuse of wastes to protect the environment in general and the soil environment in particular are prescribed only in the form of "encouragement" and are not yet expressed in the form of compulsory regulations or premiums. The environmental protection charges of waste are still not sufficiently high enough to affect the discharge behaviour; therefore, pollution remains a common problem. Farmers need to be informed and trained on environmental protection legislation regarding the process of using agricultural land to minimise the inappropriate use of chemical fertilisers, plant protection chemicals, and pesticides. Consumers need to move towards the habit of using "clean agricultural products", which is an important factor for supporting and motivating farmers to develop sustainable agriculture associated with the protection of the agricultural land environment.

Table 2 summarises the scope of regulation of the Law on Land of 2013 and its contents, which should be incorporated in environmental considerations and requirements. 
Table 2: Environmental requirements integration into the Law on Land of 2013

\begin{tabular}{|c|c|}
\hline Scope of Regulation & Environmental Requirements for Integration \\
\hline \multicolumn{2}{|l|}{ 1. General provisions } \\
\hline $\begin{array}{l}\text { 2. Rights and duties of the state involving } \\
\text { land }\end{array}$ & $\begin{array}{l}\text { 2.1. Control soil pollution; recover soil environment, and } \\
\text { combat land degradation and desertification. } \\
\text { 2.2. Propagate environmental protection in land law } \\
\text { enforcement }\end{array}$ \\
\hline $\begin{array}{l}\text { 3. Administrative boundaries and base } \\
\text { survey of the land }\end{array}$ & $\begin{array}{l}\text { 3.1. Investigate the current state of the soil environment } \\
\text { with a base survey of the land } \\
\text { 3.2. Integrate the current environmental status map into the } \\
\text { land map }\end{array}$ \\
\hline 4. Master plans and plans on land use & $\begin{array}{l}\text { 4.1. Environmental protection objectives in land-use } \\
\text { planning and plans } \\
\text { 4.2. Content of land use for environmental protection } \\
\text { purposes }\end{array}$ \\
\hline $\begin{array}{l}\text { 5. Land allocation, land lease, and change } \\
\text { of land-use purpose }\end{array}$ & $\begin{array}{l}\text { 5.1. Ensure environmental considerations in land allocation, } \\
\text { land leases, and changes of land-use purpose }\end{array}$ \\
\hline $\begin{array}{l}\text { 6. Land recovery, land requisition, } \\
\text { compensation, support and resettlement }\end{array}$ & 6.1. Reclaim land due to soil pollution \\
\hline $\begin{array}{l}\text { 7. Land registration, grant of certificates of } \\
\text { land-use rights and ownership of houses } \\
\text { and other land-attached assets }\end{array}$ & \\
\hline $\begin{array}{l}\text { 8. Land finance, land price and auctions of } \\
\text { land-use rights }\end{array}$ & \\
\hline $\begin{array}{l}\text { 9. Land information system and land } \\
\text { database }\end{array}$ & $\begin{array}{l}\text { 9.1. Current state of the soil environment in the land } \\
\text { information system and database }\end{array}$ \\
\hline 10. Land-use regime & $\begin{array}{l}\text { 10.1. Environmental protection in land-use types } \\
\text { 10.2. Land-use regime for environmental protection } \\
\text { purposes }\end{array}$ \\
\hline 11. Rights and obligations of land users & $\begin{array}{l}\text { 11.1. Comply with environmental protection obligations in } \\
\text { the process of land use }\end{array}$ \\
\hline 12. Land-related administrative procedures & \\
\hline $\begin{array}{l}\text { 13. Supervision, inspection, settlement of } \\
\text { disputes, complaints, denunciations, and } \\
\text { handling of violations of land law }\end{array}$ & $\begin{array}{l}\text { 13.1. Inspection of environmental protection in land use } \\
\text { 13.2. Handling of environmental violations in the process of } \\
\text { land use }\end{array}$ \\
\hline
\end{tabular}

\section{Roles and Benefits of Environmental + Integration into Land Law}

Implementing the integration of environmental protection requirements into land law is expected to provide many benefits:

+ Ensure the requirements of sustainable development in all decisions related to land use (i.e., ensuring that land is used sustainably);
+ Save the cost of environmental protection by preventing unintended harm to the environment (due to not inadequate calculations during the formation stage of the land use decision, for instance) and taking measures for preventing harm to the environment.

+ Raise relevant stakeholders' awareness (including government officials and civil 
society) of protecting the environment. Environmental protection issues are closely associated with the behaviour of each subject in the process of production, business, consumption and their activities.

Implementing the integration of environmental protection requirements into land law is an important solution to ensure the requirements of sustainable development in all sectors of the economy, as well as the whole society.

\section{Conclusion}

The integration of environmental considerations into land law is based on the close relationship between land and the environment. Land is both an element of the environment (along with other elements, such as water and air) and an input for many productions and living processes - activities that are closely related to the environment and likely to harm the environment. The need for the integration of environmental considerations into land law also originates from the current situation of land use in Vietnam and the provisions on environmental protection in land law. The land use that does not comply with the standards and requirements of environmental protection (for example, the use of toxic chemicals in agricultural production or the indiscriminate discharge of toxic substances onto the land) has caused many negative consequences. As a result, the soil environment is polluted and degraded.

Regulations related to environmental protection in land law are insufficient and unclear, affecting the effectiveness of environmental protection through land management and use. Therefore, the need to make land law "green" is an urgent issue to overcome the limitations of the current land law in protecting the environment and implementing the goals of sustainable development.

Regulations on environmental protection that need to be integrated into land law include a focus on integrating environmental protection requirements in land use and EIA planning, and environmental protection in the management of land use, improving the quality of arable land and preventing degradation and desertification, and raising the awareness and responsibility of land users regarding environmental protection.

\section{Acknowledgements}

The authors extend their gratitude to reviewers for critical comments on the manuscript and the university for the research opportunity.

\section{References}

Adelle, C., \& Nilsson, M. (2015). Environmental policy integration. In P., Pattberg \& F., Zelli (Eds.), Encyclopedia of global environmental politics and governance. Edward Elgar.

Ahmed, M. I. (2017). Integration of environmental safeguards into Ethiopian investment and sectoral laws. Journal of Sustainable Development Law and Policy, 8(2). DOI: https://dx.doi.org/10.4314/jsdlp. v8i2.6

Bugge, H. C. (2010). Environmental law's fragmentation and discretionary decisionmaking. A critical reflection on the case of Norway. In Røsæg, E., Schäfer, H. B., Stavang, E. (Eds.), Law and economics: Essays in honour of Erling Eide (pp. 5575). Oslo: Cappelen Damm Akademisk.

Chương trình hợp tác Việt Nam - Thuy Điển (SEMLA, 2007). Báo cáo tổng hợp các vấn đề lồng ghép đất đai và môi trường. Tăng cường năng lực quản lý đất đai và môi trường. Hà Nội - 2007.

Collier, U. (1994). Energy and environment in the European Union. Aldershot: Avebury.

Fidelis, T. (2005). Integrating environmental issues into the Portuguese planning system - 10 years of emerging challenges and persistent problems. Sustainable Development and Planning II, Vol. 1. DOI: 10.2495/SPD050331 
Jordan, A., \& Lenschow, A. (2010). Policy paper environmental policy integration: A state of the art review. Environmental Policy and Governance, 20, 147-158.

Lafferty, W. M., \& Hovden, E. (2003). Environmental Policy Integration: Towards an Analytical Framework. Environmental Politics, 12(3), 1-22.

Land Degradation Neutrality Target Setting Programme (LDN TSP, 2018). Final Country Report of the Land Degradation Neutrality Target Setting Programme. Hanoi - 2018.

Lenschow, A. (1999). The Greening of the EU: The common agricultural policy and the structural funds. Environment and Planning. C: Government and Policy, 17, 91-108.

Lenschow, A. (Ed) (2002d). Environmental Policy Integration: Greening sectoral policies in Europe. London: Earthscan.

Lê, T. T., \& Nguyễn, H. V. (2020). Bất cập của các nguyên tắc áp dụng pháp luật trong Luật Ban hành VBQPPL nhìn từ thực tiễn xử lý VPHC. Bộ Tư pháp, 5-2020.

Liberatore, A. (1997). The integration of sustainable development objectives into EU policymaking: Barriers and prospects. In Baker, et al (Eds.), The politics of sustainable development.

Mai, T. D., Nguyễn, M. K., \& Phan, T. T. H. (2019). Lồng ghép yêu cầu bảo vệ môi trường trong hệ thống pháp luật chuyên ngành ở Việt Nam - Một số vấn đề lý luận. Tạp chi Khí tương thưy văn, 10/2019. DOI: 10.36335/VNJHM.2019(706). 26-32

Mickwitz, P., \& Kivimaa, P. (2007). Evaluating policy integration: The case of policies for environmentally friendlier technology innovations. Evaluation, 13(1), 68-86.

Ministry of Natural Resources and Environment (MONRE, 2020). Five years Summary Report on enforcement of Law on Environment Protection 2014.
Ministry of Natural resources and Environment (MONRE, 2015). National State of Environment 2011 - 2015. Hanoi - 2015 (Vietnamese).

Ministry of Natural resources and Environment (MONRE, 2010). National State of Environment 2010: An overview of Vietnam environment. Hanoi - 2010.

Nguyễn, Q. T. (2009). Xây dựng pháp luật đất đai với vấn đề phát triển bền vững. Tạp chí Nghiên cưu lập pháp-2009.

Nguyễn, T. M. H., \& Đỗ, T. K. H. (2015). Giải pháp giảm thiểu ô nhiễm, suy thoái môi trường trong quá trình sử dụng đất nông nghiệp ở Việt Nam. Tạp chí Môi truoòng, số $3 / 2015$.

Nguyen, T. H. (2017). An overview of agricultural pollution in Vietnam: The crops sector. https://openknowledge.worldbank. org/handle/10986/29241

Nilsson, M. (2005). Learning, frames and environmental policy integration: The case of energy policy in Sweden. Environment and Planning C: Government and Policy, 23, 207-226.

Persson, A. (2004). Environmental Policy Integration: An Introduction. Stockholm Environment Institute. https://www.sei. org/publications/environmental-policyintegration-introduction

Peters, G. (1998). Managing horizontal government: The politics of coordination. Research Paper No. 21. Ottawa: Canadian Centre for Management Development.

Pham, M. T., Bui, N. K., \& Purizevsky, R. (2020). Legal framework for environmental impact assessment in Vietnam: The challenges between the regulations and practice. E3S Web of Conferences 164, 11008(2020). https://doi.org/10.1051/e3sco nf/ 202016411008

Runhaar, H. (2016). Tools for integrating environmental objectives into policy and practice: What works where? 
Environmental Impact Assessment Review, 59(2016), 1-9.

Thái, T. T. D. (2011). Các nguyên tắc giải quyết xung đột trong các văn bản quy phạm pháp luật. Khoa hoc pháp lý, Đại học Luật TP. Hồ Chí Minh, 2011, Số 05(66).

Tilahun, M., Singh, A., Kumar, P., Apindi, E., Schauer, M., Libera, J., \& Lund H. G. (2018). The Economics of Land Degradation Neutrality in Asia: Empirical Analyses and Policy Implications for the
Sustainable Development Goals. www.eldinitiative.org.

Underdal, A. (1980). 'Integrated marine policy: what? why? how?'. Marine Policy, 4(3), 159-169.

Vu, M. Q., Le, Q. B., Frossard, E., \& Vlekba, P. L. G. (2014). Socio-economic and biophysical determinants of land degradation in Vietnam: An integrated causal analysis at the national level. Land Use Policy, 36(2014), 605-617. 